\title{
ARTICLES ARTÍCULOS \\ JOURNALISM AND CHANGE IN THE EXPERIENCE OF TIME IN WESTERN SOCIETIES
}

Copyright (c) 2014 SBPjor / Associação Brasileira de Pesquisadores em Jornalismo

\author{
CARLOS FRANCISCATO \\ Federal University of Sergipe, Brazil
}

\begin{abstract}
The purpose of this paper is to investigate the temporality produced by journalistic practice and the ways journalism has a privilege to build a specific type of social experience of the present time. This inquiry carries out a historical journey, but it is not our purpose to present a history of press in the sense of a history of institutions, particular genres and languages. Instead, this investigation develops a historical study in order to identify social temporal phenomena produced by journalism, and to express them in the form of descriptive categories, which give regularity to a diversity of temporal phenomena: instantaneity, simultaneity, periodicity, novelty, and public disclosure. Besides, we consider this work a theoretical study that uses historical elements to analyze, through a sociological approach, fundamental aspects of a social constitution of journalistic temporality.
\end{abstract}

Keywords: Journalism. History of journalism. Temporality. Present time.

\section{O JORNALISMO E A REFORMULAÇÃO DA EXPERIÊNCIA DO TEMPO NAS SOCIEDADES OCIDENTAIS}

RESUMO- O objetivo deste texto é investigar a temporalidade produzida pela prática jornalística e os modos pelos quais o jornalismo tem a prerrogativa de construir um tipo específico de experiência social do tempo presente. Esta investigação cumpre uma trajetória histórica, embora não seja nossa intenção apresentar uma história da imprensa no sentido de uma história das instituições, gêneros particulares e linguagens. Em vez disso, desenvolvemos um estudo histórico com o objetivo de identificar fenômenos sociais temporais produzidos pelo jornalismo, e para mostrá-los na forma de categorias descritivas, as quais oferecem regularidade para uma diversidade de fenômenos temporais: instantaneidade, simultaneidade, periodicidade, novidade e revelação pública. Além disso, este trabalho é um estudo teórico que utiliza elementos históricos para analisar, por meio de uma abordagem sociológica, aspectos fundamentais da constituição da temporalidade jornalística.

Palavras-chave: Jornalismo. História do jornalismo. Temporalidade. Tempo presente. Sociologia do jornalismo. 


\section{EL PERIODISMO Y LA REFORMULACIÓN DE LA EXPERIENCIA DEL TIEMPO EN LAS SOCIEDADES OCCIDENTALES}

RESUMEN - El objetivo de este texto es investigar la temporalidad producida por la práctica periodística y los modos en los que el periodismo tiene la prerrogativa de construir un tipo específico de experiencia social del tiempo presente. Esta investigación efectúa una trayectoria histórica, aunque no es nuestra intención presentar una historia de la prensa en el sentido de una historia de las instituciones, géneros particulares y lenguajes. En su lugar, desarrollamos un estudio histórico con el objetivo de identificar fenómenos sociales temporales producidos por el periodismo, y para mostrarlos en forma de categorías descriptivas que ofrecen regularidad para la diversidad de dichos fenómenos: instantaneidad, simultaneidad, periodicidad, novedad y revelación pública. Además, este trabajo es un estudio teórico que utiliza elementos históricos para analizar, por medio de un enfoque sociológico, aspectos fundamentales de la constitución de la temporalidad periodística.

Palabras clave: Periodismo. Historia del periodismo. Temporalidad. Tiempo presente. Sociología del periodismo.

\section{INTRODUCTION}

Searching for a better understanding of the role played by journalism in modern and contemporary societies has been a task of researchers in different areas of Human Sciences, as a consequence of the growing presence and influence of the means of communication in structuring social relations. In spite of the significant advances, many communicative phenomena still depend on a better delimitation, characterization, and description.

Media systems with its structures and actions have been directly affecting the social experience of time, especially the journalistic institutions. The temporal phenomenon is an essential component of the definition of journalism and the relations it triggers in society. Journalism is a social practice that refers to the production of reports about events going on in the present time. Upon doing that, journalism acts in such a privileged way as a reinforcement of a social temporality and enabling society to construct its own experience of the present time. We consider journalism as an institutional creation, through which both the individual and society produce their social experience of the present moment. We point out to journalism as a necessary condition for this experience to be achieved in some kinds of social relations. 
The initial experiences of journalism in the 17th and 18 th centuries in Western societies and their consolidation as an institutionalized social practice in the 19th century enabled the construction of a specific type of social experience of the present time, in which a wide array of temporal phenomena achieved their specificity due to the existence and acting of the journalistic institution. We will attempt to demonstrate, in this paper, that the present time is an essential dimension to journalism. We will work on the notion of present time not only as a particular feature of a product, but also as a social phenomenon composed of social practices, meaningful relation and attributed inscribed in cultural products. These elements make temporality a concrete experience, which can be understood as a social object and is endowed with a content imbued with inter-subjectively shared by members of society.

We have developed in this article a sociological study, using a historical approach (particularly a perspective of social history) as a methodological strategy to be able to visualize temporal phenomena and to elaborate descriptive categories about three orders of social experiences concerning journalistic institutions: a) Technological factors of transporting and transmitting information; b) Industrial aspects in the shaping of journalistic organizations and their participation in an emerging market; c) The construction of new social behaviours as a result of accelerated urbanization and the development of reading habits and public discussion.

Moreover, we intend to journey along journalism's historical formation in order to identify that the temporal factor has been one of the crucial elements for journalism conformation to a set of practices, principles and values integrated in a social institution. At the same time, we will see that the plurality of aspects that compose journalistic temporality will impose an analysis of phenomena according to their specificity and interrelation to other social processes. In journalism, we will propose that this set of phenomena can be understood as an articulated and complementary dimension, which we deem proper to call journalistic temporality.

Therefore, we will highlight five temporal phenomena that journalism operates on, which are considered more appropriate to outline through descriptive categories: These are interconnected phenomena, and we do not intend, in this analytical effort, to 
separate them into independent parts. It is our intention to perceive, in their diversity, certain regularities and particularities that can give a theoretical outline to the notion of journalistic temporality.

We will propose five descriptive categories of temporality used by journalism that are related to actions, situations, and ways of approaching events in the present time: instantaneity, simultaneity, periodicity, novelty, and public disclosure. When proposing these five descriptive categories, we attempted to fit them into broad historical movements that create conditions, processes and meaning for the journalism to be consolidate, but also perceiving how internal movements in the journalistic institution constituted tensions, routines, rules, values and practices with a certain kind of independence regarding the original social processes, with strength enough to exert influence upon them

\section{JOURNALISM IS AN ACTIVITY BASED ON THE PRESENT TIME}

We understand that the present time is an essential aspect of journalistic activity in three ways:

\subsection{Development of a "culture of the present time"}

The first way can be identified by turning to historic studies in order to comprehend the emergence of journalism in western societies and to perceive that temporality was a decisive component for the understanding that a new form of social practice, related to the production of the reports of daily facts, was socially necessary. The authors we have consulted have avoided precise dates, although Hunter (1990) states, for example, that the English cultural experience at the end of the 17th century and beginning of the 18 th century had developed an obsession for contemporary life and novelty, a sharp awareness of more recent events and a desire for innovation and originality.

Newspapers and other periodicals became a new component of a written culture to deal with the transitory and mundane (SOMMERVILLE, 1996), innovating by offering "ephemeral short narratives of strange but true occurrences" (LOVELL, 1992). The incorporation of the present time and daily facts, common in conversations and oral stories as a way of characterizing the 
temporality and the content of written discourse (particularly the printed one), marked a rudimentary understanding of journalism as a social product and practice.

In his book Before Novels - The Cultural Contexts of Eighteenth-Century English Fiction (1990), Hunter focused on the study of the appearance of novels as a specific genre in English literature in the 18th century, linking novel to a modern metropolitan culture in that period, fascinated by the contemporary (FOWLER, 1993: 351). According to the author, the English cultural experience of late 17th century and early 18 th century developed a fixation for contemporary life and for novelty, partly because of a wider interest in scientific discoveries and Illuminist currents. That period achieved a sharper awareness of more recent events and a blatant desire for innovation and originality, crucial characteristics for the emergence of a new way of peculiar narrative centered on the present time that came to be called novel ("novel", word whose adjective form more precisely means "new") (HUNTER, 1988).

This cultural environment operated in an urgent sense, as if on a "now" basis, offering a perception that the moment was in itself a king of "art object". The present moment became a legitimate theme not only for temporary conventions, but also for more serious discourses, such as the literary one. Nonetheless, the author avoids to exactly point out when the "present time" became so urgent a matter in the English cultural conscience, but reminds us that the printed products helped in the proliferation of testimonials and stories about daily life (HUNTER, 1988, p. 494495). For him, journalism and novel are two forms of writing about the present time, about an isolated instant, part of a concern that exists in politics, theology, psychology and education - aspects that made Hunter call that period the "age of moment-centered consciousness" (HUNTER, 1990, p. 108-109).

The English novel had several cultural sources such as books, newspapers, personal diaries and pamphlets, which represent the cultural conscience of the time and, particularly, the awakening of a growing commitment to some aspects of modernity: the cult of novelty, innovation and the future. Newspapers (as part of group of printed products like pamphlets and posters) helped create, broaden and extend the "culture of the moment", and the modern novel would seem unimaginable 
without the peculiar combination of "News, and new Things" that became an obsession of English culture at that time (HUNTER, 1988, p. 515).

In studies like Hunter's, as well as Benedict Anderson's work (1991), which analyze the creation of an idea of national community in the 18th century Western Europe, journalism consolidates itself as a writing of events, issues and situations happening in the present moment, which are far from the direct experience of a collectivity, contributing to the creation of social and cultural relations referred to the present time.

\subsection{Temporality guides the ways of journalistic institutionalization}

The second moment of investigation about the unbreakable bond between journalism and present time considers the ways temporality guided the institutionalization of journalism both in the internal organization of its practices and definition of its product and also in the wide social relations journalism has produced. The control over time focused on the preservation of the link of the activity with the present (its currentness) became a principle of task organization and planning, routine structuring and distribution of its products.

Journalistic production in the 17 th and 18 th centuries depended, mainly and in large scale, on the ability of graphical professionals of handling rudimentary equipment (SUTHERLAND, 1986). This was a stage of gradual unavoidable transition between a very simple previous model of handwritten news ("handwritten news-letters") and a model of printed paper production ("printed newspapers"). Journalistic production technology accomplished an intensive development in the 19th century with the introduction of new printers models in the 1860s and 1870s, which were smaller, faster and cheaper: as "web rotary", rotary printers operated in an interconnected way. Daily papers were those benefitted mostly by the advance in performance of these rotary printers. Lucy Brown (1985) mentions the improvement of productivity is not only about the performance of rotary printers: a new concept of technical and organizational efficiency in the companies comes forth, even if this improvement represents a raise in costs. 
Time is institutionalized both as an identity factor and as a tension factor. Temporality gives a cultural shape to journalistic product, the news, making it recognizable and establishing its limits of meaning, acting and social existence. News have an ephemeral existence, as a consequence of the speed of the world that outdates the journalistic report or by the ways the journalistic organization applies to the volatile mechanisms for its regular substitutions or its permanence in successive unfolding. The news bring, usually explicitly, marks of the present time that affirm a temporal singularity, its brief duration in the expression of a fading present.

Contrary to that, journalistic temporality is an experience of stress between two movements: on the one hand, there is the speed of a changing world, so fast, unequal, and irregular; on the other hand, the speed of journalistic discourse production about this. Journalism faces a permanent risk of having the sense of time of its discourse detached from the timing of the world. At the same time, the journalistic institution developed procedures and techniques of legitimization and affirmation of its capacity to overcome the risk of disconnection from the timing of the world and the timing of journalistic production. Journalism is a report about something that belongs to the present time, a temporality defined by habitual and symbolic relations of reference to human actions, even if one event just happened some moments ago.

\subsection{Journalism contributes to the social construction of the present time}

Understanding journalistic temporality as a central aspect of journalism consists, regarding a third aspect, of stressing journalism not only as stories about events in the present time, but as a social force which acts in the building process of the social experience of the present time. Its institutional production of current content offers to society specific forms by which the individual and society produce their social experience of the present moment, making it oftentimes one of the necessary conditions for this experience to be accomplished in some social relations.

Hence, we are pointing out that the present of the time of reference for the human action to take place. The time of 
journalism is bound to the time of events, themes and situations that are on vogue, in constitution, on the move, and interferes in two ways in this temporal construction. On one hand, in the social definition of certain events, understating as an event a social construction based on situation that acquire a collective characterization and recognition through symbolic operations. Events have their own time flow and both are constituted from institutional factors. The production of the journalistic event implies since its beginning a need for cutting off time flow. Journalistic events are not only symbolic milestones about the present time, but are also temporal definition about ways of experiencing the present.

Sommerville considers that journalism disseminates a factcentered discourse throughout cultures. Still in the hybrid productions called "corantos" in early 18th century England, periodic reports on events could be identified with a precise location in time and space, a tendency to write "straight to the point" and to produce exact reports, with the identification of sources and a sense of conclusion in each text, even if for a reality still under development. Numeric data, lists and other resources were used by reporters to give a sense of objectivity to the news (SOMMERVILLE, 1996: 11;66). At the same time as journalistic news would have an abrupt closure created by the reporter's view point (the 'final episode of the day or week'), it could also bring a reference or invitation for the reader to crave for the next edition and to follow up the sequence of a story the next day or following week.

Besides the temporal definition of journalistic events, journalism produces a temporal meaning at the moment of its social circulation, by enabling processes of discussions, formulations and executions of social actions to take place in a specific manner at the present moment. The news subsidizes the construction of social actions, whether in definition of the social agenda of public affairs, or in motivating debates, formulation and conduction of public decisions.

Daniel Woolf investigated the formation of a sense of present in this period and considered the role news had to create a "zone" between past and future whose definition according to Woolf, offered us a space for discussing current events. Raymond $(1999,133)$ and Barker $(2000,1)$ realized that in 1718 and 19th century England that there was a high degree of dependence of 
the population on newspapers in their process of public debates. Harris (1996: 97-98) noted how the press became a forum for the presentation of rational arguments, thus contributing to the development of a policy of respectability, characterized by order and peaceful persuasion.

Therefore, the present time can be understood as a central aspect of journalism when we realize there is a fundamental synchronism between journalistic timing and the timing of a series of public actions in the making (PARK, 1955), both linked to a flourishing of the present world. The participation of journalism in the construction of present public temporality varies according to the type of reporting event, its expressive shape and its means of distribution, reception and the social context the news and actions will interact.

\section{JOURNALISM AND THE SOCIAL CONSTRUCTION OF THE PRESENT TIME}

The plurality of aspects of temporality in journalism has pressed on us the need to analyze different phenomena according to their specificity and at the same time, has made us consider that these phenomena are part of the same articulated complementary dimension we call journalistic currentness. Throughout the historical journey, we managed to visualize at least five types of temporal phenomena interwoven in the journalistic activity. In order to make them perceptible and operative in their specificity, we are proposing here a definition of five descriptive categories of these phenomena that achieve a social objectivity and concretization in social relations and relations of sense.

We know those phenomena are linked and we are not intending, with this methodology, to separate them into independent parts. However, in our view this analytical effort can help us to perceive mechanisms and differentiated relations that the social actors (journalists, journalistic organizations, social institutions, and their audience) establish with their products and social processes in each type of temporal phenomenon involved.

It is understood these phenomena were historically constituted as part of a process of formation of journalism itself as a social institution. Therefore, we will use some historical and social 
experiences as exemplifying situations to describe manifestations of the temporal factor in journalism.

\section{a) Instantaneity}

The category of instantaneity in journalism was based on two main references. The purpose of the first was to underscore the dimension of physical materiality of instantaneity, referring to an absence of a time span between an event and its record, transmission, and reception by an audience. From a historical perspective, instantaneity was not an effective achievement in the early centuries of journalism. However, the temporal phenomenon this category expresses became better outlined in the gradual evolution in the speed of the transmission and distribution of news and their means of production. The gradual conquest of shorter intervals in the movement of events created a feeling that the time of occurrence of an event was each time closer to the time of its reception.

A second historical reference of instantaneity had a social-cultural dimension. Instantaneity became both a norm of journalistic practices in order to ensure its "speak about the present time" report and a cultural sense that makes the journalistic product identifiable as a content of currentness. Instantaneity characterized a sense of time in which the journalistic events were nestled close to the present time of the reader's daily experience, whose sensation was intensified with the progressive acceleration of the journalistic production rhythm.

At the same time, it is unthinkable under our contemporary conception, that the term instantaneity could be used in Europe in the 17 th and 18th centuries, for example to refer to the act of reporting and sending the newspapers handwritten letters by correspondents located far away from the headquarters in order to report them about news from the provinces, using the post service of the time with its periodicity being amplified. Also it is unreasonable to speak of instantaneity when we consider foreign news of that time, when a precarious network of transmission caused information about an event in a foreign country to take days to arrive to the newspaper, as it depended on the irregularity of the means of transportation (in the case of England, ships were used to carry news from the continent). Some newspapers only learned about the news after they had been already printed by other foreign publications, which 
caused a considerable interval between the event and its effective reading (BARKER, 2000).

The means of transportation have really provided us with structural conditions for the apprehension of movement and speed in different societies. Before the advent of the railroads, for example, travelers had to face the precarious roads and the treacherous river currents in fragile vehicles and boats, what made them more exposed to weather adversity. The emergence of railroads and locomotives in the 19th century brought three direct advantages to newspapers: reaching the public in far-off places and gathering the news throughout national territories; reducing the time for the transportation of newspapers; and giving a better regularity to transportation, with the appearance of the control of time schedules for the departure and arrival of trains (BROWN, 1985: 7; WHITROW, 1993: 181). Even so, none of these factors led us to a sense of instantaneity in communications.

According to Woolf (2001), it was literally impossible, before the advent of the telegraph, for an event to be immediately perceived from a large distance. Thus, the first great promise of an instantaneity in journalism came with the telegraph. However, its transmission potential was visibly limited: only sending the signal was simultaneous and depended on a network of wires connecting two transmission stations and also depended on sheer luck counting on the fact that no downtimes or interruptions would occur during the transmission. All the journalistic process (of which the telegraph was constitute, in the beginning, only a feature of connecting the reporter to the newspaper headquarters) had a relevant time consume, as it implied the codification/recodification of news texts in telegraphic signal, a work that was also time-consuming if the text was too long (BLONDHEIM, 1994).

In other words, the coming of the telegraph accelerated the process of producing news, as it established a resource for instantaneous transmission from a point to another, but such instantaneity did not expand to other stages in the process of production and distribution of newspapers. Nevertheless, the social and cultural effect of this acceleration in transmission was fantastic for the creation of a new sense of recentness and briefness in the production and in the news content, as well as for the reinforcement, in the audience, of its bond with the present time in the unfolding events.

Technological advances in transmission of information and 
its applicability to journalism created, for reporters and editors, new possibilities and challenges for updating newspapers in the last decades of the 19th and 20th centuries. With Fedler (2000), Berger (1951) and Brown (1985) we can identify four innovation that have brought intense changes about the journalistic work: the telegraph, the telephone, the linotype machine and the typewriter

Besides the already described telegraph, it is interesting to mention the reporters' different reactions concerning the telephone: initially, a kind of distrust was cast on the new tool, as few sources had the device and the reporters believed they could have better interviews when face to face with their sources. On the other hand, using telephones was understood as new way of laziness and slackness of the reporters by not wanting to commute from the locations of the interview and assessment. This distrusting culture added to the laziness factor was being modified particularly with the contribution the telephone brought for time control: reporters at the times of closing an issue started to use the new resource to send reports, to the editorials; from the places they gathered (FEDLER, 2000).

The applications of telephone as a journalistic tool at the end of the 19th century also accelerated the means of journalistic production, although in ways similar to those of the telegraph. Its main initial effect concerned the work of the reporter on assessing and transmitting information to the newspaper headquarters. Now, information could be obtained by telephone in places with the device, as police departments of the big cities (BERGER, 1951). The introduction of the linotype machine and the typewriter in the last decades of the 19th century helped editors and graphic professionals to write and compose texts for printing. The linotype machine brought an evident and economical advantage and time spare in the production, especially for editors and businesspeople it was possible to publish more pages in the newspapers, accept a larger number of ads, reach a wider distribution and print new issues of the newspaper during the afternoon (FEDLER, 2000).

Therefore, the sense of instantaneity that newspapers built based on this technology available until the first decades of the 20th century was limited to the ability of presenting to the reader, in its daily periodicity or through "extra" issues, reports about events that happened some hours before the newspaper 
distribution. This way of producing and distributing the newspaper would keep creating and stimulating a conception of instantaneity until the technology of the radio and later the television came to develop "live" means of communication and transmission, directly connecting both the journalist and the developing events to their audience, overcoming time spans in transmitting and distributing news. These bonds redefined the contemporary sense of instantaneity in journalism and introduced new ways for the journalist to act as a social mediator.

\section{b) Simultaneity}

The category of simultaneity was a landmark for a new possibility of temporal experience: the capacity to synchronize actions or events that took place at the same time, even if they did in different speeds of occurrence, duration, consequences or unfolding. Calendars and clocks were, in the history of civilizations, initial resources to give society the power to perceive events from far-off distances could happen simultaneously.

Simultaneity was manifested, on one hand, in the technical ability to synchronize complex events and their application on economical production and, on the other hand, in the ways of establishing new relations and meanings for social actions and cultural productions. Benedict Anderson (1991) researched the simultaneity in the 18th and 19th centuries as a socio-cultural manifestation of a public sense of community that dwells at a time and space outlined (the "nation") and realized the newspapers played a special role in this relation: the act of reading newspapers continued a social habit (a ritual) in certain periods of the date and the journalistic content made individuals to feel as if they participated (whether in a real or imaginary way) in the actions and decisions that involved the community as a whole.

The newspapers created in the 19th century, new complex relations of simultaneity according to Benedict Anderson (1991), when he described the advent of a conscience of the newspaper reader who daily operates and reconstructs themselves at every moment the newspaper is published and distributed. Anderson uses the anthropological term of a "mass ceremony" to describe this paradoxical act: on one hand, an almost repetitive, daily and usual movement of receiving the newspaper each morning, sitting down and reading with eagerness; on the other hand the conscience that 
this reading is carried out by a wide audience, spread by the area of distribution of the paper, and that from this reading unnumbered actions will be interpreted defined, modified or questioned, where in home discussions or in public spaces.

The increase in the speed of social processes and the technology of transmitting information by the end of the 19th century turned simultaneity into a complex social and cultural experience. Events seem to multiply by the eyes of society under technologies that allowed situations of simultaneity, and expressions such as a "thickened present", "thickened present" in Kern (1995) and "understanding of time-space" (HARVEY, 1993) are formulated to describe this expansion in the horizon of things that can be experienced at the present time.

Another largely impacting social factor of the 19th century was the introduction of a uniform world-level time standard affecting activities as unequal as communication, industry and even wars, by the control of punctuality and standardization of time measuring instruments. Uniform times stimulated a control of punctuality, synchronicity and uniformity of instruments to measure time (WHITROW, 1993).

Kern uses the category "simultaneity" to show how new technologies or artistic technologies can spatially expand the present experienced as an individual or a collectivity. If there is the ability to overlap, synchronize or access more than one environment or relation of physical experience at the same moment the present time ends up being spatially multiplied, allowing several experiences to be simultaneously employed (KERN, 1983). That is, the phenomenon of simultaneity allowed the sense of present time to be experienced by different groups of people located in different places - the author states, "simultaneity extended the present spatially" (KERN, 1983, p. 81).

The simultaneity journalism produces is one of the ways to make a social group (or at least a part of it) overcome states of social atomization and are stimulated to act in a minimally coordinated way, not only in the actions, but also with the concepts and values regarding the events described in the newspaper and the others, absent in the journalistic pages, but correlated in basic characteristics to those reported.

Another type of relations of simultaneity in journalism has both aesthetic and social components. Cultural experiences 
of simultaneity at the turn of the 19th and 20th centuries showed new possibilities of combining "discourses", with the ways of building images, polyphonies of voices, intercalations of narratives and actions and the breaking of linearity in the report about the unfolding event, according to Kern (1983). Journalism does not execute so deep a plunge into these languages of deconstructing and constructing impressions, images and events as poetry, music, painting, literature or cinema. Even so, the newspaper page carries characteristics that are similar to these aesthetic experiences and, at the same time, the newspaper is somehow a particular aesthetic experience.

The newspaper works with a temporal factor that leads towards an initial point of cohesion of a newspaper page: the journalistic texts jointly speak of events that occur simultaneously. However, this "coexistence" in the page space does not come without tension. In order to make it intelligible and harmonic, the journalist pursues the establishment of diverse relations among events, which, since the very beginning, may not have had a direct relation.

The simultaneity of this "polyphony of voices" is in journalism a construction factor of specificity in content and textual structure. Both are temporally linked to the "time of the event", but it is up to journalism, operating with an effort to build a sense of currentness that will reformulate these elements. Somehow, the journalistic currentness arises from a "polyphony of voices" - it arises in order to attempt to overcome the temporal disparities and construct a discourse that will articulate and minimize differences, fragment and rearrange contents to achieve a minimum harmony in its product from a temporal reference of the present.

\section{c) Periodicity}

Periodicity is one of the most crucial temporal phenomena of journalism specificity in its very beginnings. The establishment of a journalistic production in regular intervals and fixed by incipient organizations of the 17 th and 18 th centuries redefined and reordained ways of socially experiencing time. Regular production of news gave society a continuous involvement with events, developing standards of remembrances that allowed events to be followed as they unfolded and maybe perceive causal relations (RAYMOND, 1999). Furthermore, the regularity in the 
offer of news ensured an ongoing feed of information to boost public debates and decisions.

Outlining the initial moment a publication with journalistic content start to circulate with regular intervals is no easy task, as we would have to consider all details from the "corantos" and the "newsbooks" in early 17th century England, some with monthly or bimonthly and others on a weekly base. However, this periodicity was regular, for it oscillated according to the volume of news available (RAYMON, 1996). Schröder analyzed the German case to consider the absence of periodicity before the 16th century prevented the publication with diversified information to be considered "newspapers". Before the advent of newspapers in the 17 th century, some occasional publications covered and published reports about a certain event according to its unfolding and the number of its issues was limited to the duration of the event, with no planed regularity similar to the model of periodic publications with fixed dates. Schörder makes a curious account that the absence of periodicity could also be an advantage as it made it harder for censorship and governmental control, differently from what happened to weekly newspapers that came later. Vittu studied the arising of newspapers in France in order to consider that the 17 th century was the time of the "periodic press" (2001, p. 160). Likewise, Daniel Woolf interpreted that the temporal regularity of "newsbooks" came forth right in the middle of the 17th century from the need of these publications to follow the implications of political facts in England.

Perhaps one of most systematic historical studies ever developed about journalistic periodicity is John Sommerville's work, The News Revolution in England - Cultural Dynamics of Daily Information (1996), in which the author researches about the temporal aspect in the formation of English journalism in the 17 th and 18 th centuries. The beginning of the 17 th century was a phase where English publications with journalistic content presented an irregular periodicity with elevated time span between each issue: an average of a publication with two or three weeks between the decades from 1620 to 1640. In the tow following decades, the weekly periodicity became dominant and the "key for these publications to reach the reader's fidelity and a commercial success". Editor preferably chose for the distribution of new editions on Mondays, thus they could send them to the inner 
parts of the country using weekly shipments of postal services on Tuesdays. Mondays became days of competition amongst these products (SOMMERVILLE, 1996).

This panoramic view of the advent of periodicity is not, for Sommerville, a positive social change in society. It is quite the contrary. The author interprets through a pessimistic perspective. Initially, because he sees it as a consequence of a preponderant commercial interest that could affect the entire set of the other social relations. Joad Raymond contests Sommerville's approach by understanding the authors of this argumentative current attribute to the flow of periodic circulation of journalistic contents, a causative factor from a "culture of passivity" and of "forgetfulness". Instead, Raymond interprets that periodicity has become an essential attribute of "newsbooks" and "newspapers" by ensuring a continuity of information distribution and hence the debate. For the author, periodicity developed standards of remembrance and active involvement of readers in the events and debates (RAYMOND, 1999).

The first model of periodicity to be consolidated in western societies was the weekly one: most of the newspapers from the 17th century were printed once a week in Europe. Even with the beginning of the production of newspapers with three weekly issues, newspapers with single issues at the week lasted longer throughout the century, as they printed a larger number of pages (six pages against two of tri-weekly papers) as a competitive strategy (SUTHERLAND, 1986). Such weekly interlude between issues was being gradually reduced during the period: at the end of the same century, $64 \%$ of German newspapers were already distributed twice a week and other $7 \%$ had three or more issues per week (POPKIN, 1989).

Journalistic periodicity was institutionalized as a way to order social time as much in the aspect of controlling normatization as in creating material or symbolic social forms, practices and processes. This means that periodicity arose as a particular phenomenon, but implied in complex relations. In an internal scope of journalistic organization, periodicity contributed to the creation of internal relations in the journalistic organization characterized by a precise control of time and the stages of production and a strictly schedule planning of actions and tasks. This normatization of time penetrated in the individual 
perceptions and ways of using time as a reporter, articulation individual and organization in a one single movement at the same harmonic and conflicting time.

The periodization of newspapers directed ways of defining and shaping news. The time span between two successive issues comes as a boundary to outline the temporality of events, indicating its temporal validity as potentially noticeable. Producing news implied the fragmentation of events in temporal cuts according to the periodicity of the publication. In a macro social dimension, this way of operating the event's temporality contributed to the redefinition of public temporality: mutual influences between the journalistic activity enabled the journalistic product to be associated to the rhythms of daily life and to the journalistic organization.

\section{c. 1) Daily Periodicity}

Intense urbanization was a general phenomenon in the development of European countries and the Unite States of America in the 18th, 19th and 20th centuries, especially if we consider that their growth was interconnected to complex social changes such as industrialization and the commercial growth, the expansion of transporting network and immigration. Cities that concentrated these transformations more intensely became metropolises, like London, which achieved more than 4 million inhabitants still at the end of the 19th century (BROWN, 1985).

Daily life rhythm, one of the main nature and cultural units of organization and time measurement' gained a series of temporal markings with the increment of urban routines and dynamism, as Alain Corbin described when he investigated the French case of the 19th century. Social institutions like schools and companies, concentrated mainly on metropolises, played a strong role in this social regulation of time. Schools developed pedagogical modes based on a written time control that became a reference for developing strict discipline imposed on students with their family's consent. Severe time managements started to become obsessions for managers in jails, hospitals, industrial schools and even asylums, where time supervision soon became an essential element in therapies (CORBIN, 1995).

Factories also became a model in time control for other 
companies through a temporal rationalization of practices and regulations to be gradually internalized by individual who had their own personal time references previously, such as those workers who had come from the countryside. The State created legislations that defined the duration and distribution of working time for children, women and the working force as a whole. Corbins considers that the action of institutions by imposing social times can be interpreted as a standardization and regularization process stage of familiar and individual experiences of time. The internalization of norms was probably most visible at the base of the social pyramid, an action to control leisure time and impose the bourgeoisie's maxim that "time is money" (CORBIN, 1995).

The acceleration of urban life rhythm happened at the convergence of factors like industrialization, market, communications and immigration. Improvements in transports introduced a dynamic pace in the landscape of big cities. Collective transports gradually altered the profile of the working class, which had to previously in most of cases to commute on foot towards their jobs and now could use urban trains, as Schudson describe (1978) when reporting a drastic change in geographic mobility in North-American cities at the end of the 19th century and beginning of the 20th century. For the author this fact brought along profound consequences for newspapers because middle-class people by taking a bus or a train to go to work, no longer had to worry about their journey (1978). For Lucy Brown (1985), the idleness imposed to passengers on trains was also a stimulation to reading.

Daily periodicity (the main marker of circulating journalistic temporality) was only reached in the 18 th century, starting with Daily Courant in 1702 (RAYMOND, 1996). In the North-American case, the two first daily newspapers were first published in 1784 (The Pennsylvania Packet and Daily Advertiser and The South Carolina Gazette and General Advertiser) (LEE, 1923). In the North-American case, the two first daily newspapers were first published.

The distribution of newspapers also produced a specific temporal relation according to the period of the day they were sent to the streets. The regular issuing of morning and afternoon newspapers was an adaptation to habits of readers and to the stark competition for the possibility of taking to the audience the 
latest news. The dynamics of daily life rhythm in the big cities contaminated newspapers in such a way that even the existence of two daily distributions could not inhibit the resource of the "extra" issue during the day when it was deemed necessary and convenient. Blondheim (1994: 23) considers that the emergence of the "extra" issue around 1840 in New York was possible due to innovations in the distributing services: more popular newspapers already had a network of boy sellers ("newsboys") at the streets all day long and their printing structure was organized to print a large volume of newspapers within a minimum time. According to the author, an extra issue could not only outdate the competing newspaper, but also gave prestige to the newspaper itself. Jointly considered, such stroke contributed to incentivizing the "speed" as a pace of producing news.

\section{d) Novelty}

We realize that since the first regular experiences of journalism still in the 17 th century, reporting an event has meant to take to the audience a telling of something new that arises in the social environment and drives importance or curiosity for a community. Journalism historians identified that the "novelty" in a piece of news could be captured in characteristics such as "freshness" or "recentness", highlighting a peculiar trace that fitted countless situations about daily life in communities, matters of social interest and involvement, governmental actions and details about the aristocracy.

The proposition of the category of "novelty" to describe a specific aspect of journalistic temporality intended to show that news is not dissociable from the logics of innovations, originality or renovation that standardizes the way of recognizing and defining events and publicly presenting the through a journalistic report. Novelty leads us to a bonding with the journalistically reported "new" at the present time of things that flourish in the temporality of "now".

Journalistic novelty is standardized on order to allow journalistic to produce news as a complex object, in a manufacturing process that starts with an initial raw material (the arising new) to give socio-cultural identity to the journalistic product. Journalism depends on the novelty as a way of instruction 
and recognition, for the journalist and the reader that events or their facets are birthing news in a social environment and should be journalistically reported.

Transformation of a new occurrence into a journalistic event depends, however, on the interweaving of this arising new as a rupture or change and a state of continuity in at least two aspects: firstly, through the consolidation of standard interpreting frame in order to recognize the new as a difference regarding the state of permanence; secondly, through the operation of these values in daily and organizational procedures that limit the possibilities of pursuing the "new" and stimulate the recurring exploration of some topics, sources and institutions to the detriment of others.

The journalistic institution was historically formed to become operational and to regularize public availability of novelty as a form to respond to an expectance of widening social and cultural experience of the present time. Yet, this a manufacturing process that tends not to be easily perceived by the reader and novelty seems too rooted in the event, as a spontaneous irruption.

Journalism historians constantly describe the growing interest for news on daily life, matters or social interest and involvement, actions of the State or details about the aristocracy, which became more intense as off the 17th century. Reports such as Raymond's (1996), Schröder's (2001), Blondheim's (1994) and Woolf's (2001) help us to realize different behaviors of readers, whether they were motivated by an excessive curiosity of "others' lives", worried about relevant matters for the directions of the nation or interested in knowing facts and situations in development in society in the State in order to feel more involved and integrated to social and political life of that time. What the authors identified as "novelty" in the news of that time were characteristics of ("freshness") or "recentness", which could cause from a certain wonder at the new capacity of access to facts of the present time that were simultaneously happening and at the distance of direct content to the state of anxiety or suspicion about this intense exposure of the present aspect.

In this period, the historical account was far denser and more vigorous with greater authority than the journalistic report. Whereas the former brought to the audience new facts and hence 
devoid of demonstration of proof, was seen with a certain kind of suspicion, both because its content was new (therefore different from the renowned "old texts") and harder to be verified. When they were orally transmitted in the 17th and 18the centuries in public squared or coffee houses, these contents could barely be different from mere rumors. Even the printed text did not have the credibility of the handwritten text (WOOLF, 2001).

In spite of that, this suspicion was not enough to eliminate the "appetite" of the population for "novelties" brought in the reporting texts. Editors of "newsbooks" of the 17th century already incorporated this desire for news as a new allure of their publications and exerted a visible "determination to be first", procedure that stimulated the pursuit for more recent news, even at the expense of the precision and reliability about the journalistic content. This reality turned the rumor and the journalistic error into two "public institutions", as Daniel Woolf (2001, p. 106) interprets.

\section{e) Public revelation}

The category of public revelation was proposed aiming for showing that journalist is not only a record of present time, but also a way of building this temporality in its inherent discursiveness. The journalistic discourse not only brings a sense of holding the present time inscribed in the intentions of its production and in the brands of its product, but it also intervenes in the construction of time to be worded in discursive rules shared by the counterparts (the journalistic institution and its audiences). The journalistic wording way itself is an affirmation of the "currentness" of its content.

Understanding that situations analyzed in the history of journalism and in some contemporary concrete experiences served to highlight a specific component of journalistic currentness: the wording is a privileged moment of establishing an interaction in the present time. The time of wording for journalism is a "ground zero" at the time of public distribution of news, from which it becomes a "public document" (PARK, 1955).

We use the expression "public revelation" to characterize that journalism performs a procedure of disclosing a new content to its reader, letting them know something that was off-limits to the general public. This public unawareness can result from the peculiarity of an event that comes anew in the social aspect, 
but can also be a consequence of a content or situation that occurred in the private sphere of secrecy and that the "look" of the journalistic institution (its values, criteria and noticeability and their ways of assessment and expression) point out to the need of making it public.

Some historical records have allowed us to highlight the temporal aspect of discursive interaction, which if not directly built in and by the journalistic institution, had in the journalistic contents a resource to catapult them and give them specific meaning. Discussions in European coffee shops especially in the 18th and 19th centuries had a journalistic content as an object and a stimulator od debates: News loud reading, the attentive listening and the different kinds of discussion reinforced journalism bond with the present time of the groups in the processes of constitution of their identities and interests, conceptions and values, as well as enabled them to instruct and define their resulting actions (RAYMOND, 1999; HUNTER, 1988). This means that the time of discursive interaction stimulated by journalism marked a sense of presented time for its audience not only in the announcement of the journalistic content, but also in their public discussion.

If, on one hand the journalistic institution consolidated a strategy that stated the presented time in the discursive relation it create with its audience (whether the frequent reader of newspapers in the private space of their home or the one who received the news content in public hearings at coffee shops in European countries in the 18th and 19th centuries), on the other hand, the ways these contents were spread in a dynamic discursive interaction especially in public places are, in themselves, a second factor that underscores the present temporality. Using newspaper as an object of reading and public discussion meant that the current events that dominated the journalistic contents were not only objects, but also motivations for discussions and collective actions. The present temporality that the newspaper brought by its current content actually became a temporal reference of the visitors (HUNTER, 1988).

The category of public revelation intends to describe some types of relations between newspapers, society and State. Under Habermas's view, newspapers have become a "institution par excellence" (1984, p. 213) of the public sphere because they played a hybrid role of supplying the audience with contents concerning 
matter of the State and society as well as giving a space for debating ideas and actions. It is visible that the press started to play a crucial role of publishing acts of the State: to give public transparence to its actions, breaking the domination of the secret.

Raymond's example (1996) about the "newsbooks" reinforces this role: Around the 17th century, these publications made public many debates and decisions that took place in the English Parliament and were inaccessible to a broad audience. Raymond also identified in readers a rational ability to formulate arguments based on printed texts and this incentive may have been the greatest contribution of newspapers to the spirit of critical debate in 17th century England according to the author.

Newspapers became means of information, verification and manifestation of questionings regarding a varied range of public actions and situation, particularly governmental actions, feeding what was almost an obsession for breaking the sphere of secrecy in which such public administrative acts were involved. The newspaper concentrated a great deal of this new state of spirit because it developed mechanisms to reveal protected contents of public knowledge that happened at the present time and to expose them to an audience every day keener to learn about subjects related to the same temporality of their daily lives. Just like stately actions were susceptible to the breach of secrecy, so were matters related to tragic, bizarre or daily situations of public personalities, such as members of the nobility, were also objects of public revelation.

The category of public revelation intends to describe this double articulated movement: the act of revealing something through journalistic assessment and its publication exactly by its public distribution. Both moments solidify the present time with discursive forms that create events like symbolic products and contribute to the substantialization of present experience.

\section{CONCLUSIONS}

Throughout this article, we intended to demonstrate that changes brought upon by journalism in the social experience of present time in the 17 th and 18th centuries enabled the construction of a mapping of temporal phenomena and their systematization in descriptive categories. We proposed a set of five categories that can 
delimitate journalism's main temporal manifestations: instantaneity, simultaneity, periodicity, novelty, and public disclosure. We are not saying this is the only method of theoretically dealing with the social dimension of journalism temporality, but we do consider the journey thus trodden achieves a considerable success.

The effort of theoretical systematization above demands a complementary observation: the temporal categories herein presented cannot be seen only through an isolated optics, but related to one another. Journalistic currentness is not the sum of individual temporal characteristics, but an intertwining among them, as these manifestations are particular of a common way of experiencing the present. The difference in the importance of certain phenomena to distinguish this temporal experience must be considered and, consequently, it must be also highlighted that some aspects have been more pivotal than others for the journalistic construction of a sense of present time in some given periods.

The consulted bibliographic sources allow pointing out an outstanding of categories of novelty and periodicity in the initial delimitation of the news bond to the present time. Novelty was the manifestation of a more primary and more primitive temporality, as it qualified an event from a singular intention of presenting a new truthful report to an audience. Periodicity arose as a constructive procedure of regularity in the production and offer, with clear consequence for the newspaper characterization as a "journal" and in the enclosure and conformation of the news. Periodicity is a component that modified social relations upon driving reading habits and reader's involvement in unfolding events.

Periodicity provided with parameters to organize journalistic activities in small productive units and in their relation to the audience, as well as indicated limits for journalistic content production. The embarrassment imposed by weekly periodicity from around the 17th century established a greater rigor in using time, limiting the possibility of producing reports on new events. Fulfilling the established periodicity meant, at the same time, to continue to guarantee the novelty of the news and also their veracity even if the expediency of the production would throw a certain king of mistrust upon the journalistic production as for the effective capacity of the report to be faithful to reality it was supposed to describe. 
We understand that the term "journalistic currentness" is more adequate to gather this complexity of meanings than the temporal phenomenon achieves in journalism. Although the journalistic currentness gains meaning imbued in the activities and conceptions innate to the journalistic institution, it has many ramifications by a large array of social practices. The categories presented seek to describe specific types of temporal phenomena that journalism operates, which have social objectivity, for they are concretized in significant social relations, oftentimes from determining structures.

We have proposed categories components of the notion of journalistic currentness, as we understand there is a recurring absence of conceptual construction in the studies of journalism. For us, it is hard to think of the temporal dimension of journalism without using them or the phenomena they describe. The notion of journalistic currentness is in this approach a result of a composition of phenomena extracted in the form of categories, without the convergence or interrelation, which seem to be precarious for us to deem substantive and theoretically speaking the phenomenon of journalism itself.

\section{| REFERENCES}

ANDERSON, Benedict. Imagined Communities - Reflection on the Origin and Spread of Nationalism. London and New York: Verso, 1991.

BARKER, Hannah. Newspapers, Politics and English Society, 16951855. Harlow, England: Longman, 2000.

BERGER, Meyer. The Story of The New York Times - 1851-1951. New York: Simon and Schuster, 1951.

BLONDHEIM, Menahem. News over the Wires - The Telegraph and the Flow of Public Information in America, 1844-1897. Cambridge, Mas.: Harvard University Press, 1994.

BROWN, Lucy. Victorian News and Newspapers. Clarendon Press: Oxford, 1985.

CORBIN, Alain. Time, Desire and Horror - Towards a History of the

Senses. Cambridge: Polity Press, 1995. 
FEDLER, Fred. Lessons from the Past - Journalists' Lives and Work, 1850-1950. Prospect Heights, Illinois: Waveland Press, Inc., 2000.

FOWLER, Bridget. Before Novels: The Cultural Contexts of EighteenthCentury English Fiction. The British journal of Sociology. Vol. 44, n 2, London: Routledge, June 1993, p. 351-2.

HARRIS, Bob. Politics and the rise of the press - Britain and France, 1620-1800. London and New York: Routledge, 1996.

HARVEY, David. A Condição Pós-Moderna - Uma Pesquisa sobre as Origens da Mudança Cultural. $3^{a}$ ed. São Paulo: Edições Loyola, 1993.

HUNTER, Paul. 'News, and new Things': Contemporaneity and the Early English Novel. Critical Inquiry. Vol 14, Spring 1988, p. 493-515.

Before Novels - The Cultural Contexts of Eighteenth-Century English Fiction. New York: Norton \& Company, 1990.

KERN, Stephen. The Culture of Time and Space 1880-1918. Cambridge, Massachusetts: Harvard University Press, 1983.

Wireless World. In: CROWLEY, David; HEYER, Paul. Communication in History - Technology, Culture, Society. 2nd. ed. New York: Longman Publishers, 1995, p. 228-232.

LEE, James. History of American Journalism. New York: Garden City Publishing, 1923.

LOVELL, Terry. Before Novels: The Cultural Context of Eighteenth Century English Fiction. The Sociological review. Vol. 40, $\mathrm{N}^{\circ} 1$. London: Blackwell Publishers, Feb 1992, p. 209-11.

PARK, Robert E. News as a Form of Knowledge. Society- Collective Behavior, News and Opinion, Sociology and Modern Society. Illinois: The Free Press, 1955a, p. 71-88.

POPKIN, Jeremy. News and Politics and the Age of Revolution. Jean Luzac's Gazette de Leyde. Ithaca and London: Cornell University Press, 1989.

RAYMOND, Joad. The Invention of the Newspaper - English Newsbooks - 1641-1649. Oxford: Clarendon Press, 1996.

The Newspaper, Public Opinion, and the Public Sphere in the Seventeenth Century. In: RAYMOND, Joad (ed.) News, Newspapers, and Society in Early Modern Britain. London: Frank Cass, 1999, p. 109-140.

SCHRÖDER, Thomas. The origins of the German press. In: DOOLEY, 
Brendan; BARON, Sabrina (eds.). The Politics of Information in Early Modern Europe. London and New York: Routledge, 2001, p. 123-150.

SCHUDSON. Michael. Discovering the news: a social history of American newspapers. New York: Basic Books, 1978.

SOMMERVILLE, C. John. The News Revolution in England - Cultural Dynamics of Daily Information. New York: Oxford University Press, 1996.

SUTHERLAND, James. The Restoration Newspaper and its Development. London: Cambridge University Press, 1986.

STEPHENS, Mitchel. A History of News - From the Drum to the Satellite. New York: Penguin, 1988.

WHITROW, G. J. O tempo na História - Concepções do tempo da pré-história aos nossos dias. Rio de Janeiro: Jorge Zahar Ed., 1993.

WOOLF, Daniel. News, history and the construction of the present in early modern England. In: DOOLEY, Brendan; BARON, Sabrina (eds.). The Politics of Information in Early Modern Europe. London and New York: Routledge, 2001, p. 80-118.

CARLOS FRANCISCATO is a journalist. He is a professor at the University of Sergipe (UFS) He received his $\mathrm{PhD}$ in Communication and Culture from the University of Bahia (UFBA). 